\title{
Indigenous (im)mobilities in the Anthropocene
}

\author{
Samid Suliman (D) ${ }^{a}$, Carol Farbotko (D) ${ }^{b}$, Hedda Ransan-Cooper (iD), \\ Karen Elizabeth McNamara (iD) ${ }^{d}$, Fanny Thornton (iD) ${ }^{\mathrm{e}}$, Celia McMichael (1D) ${ }^{\mathrm{f}}$ and Taukiei Kitara ${ }^{\mathrm{g}}$
}

aSchool of Humanities, Languages and Social Science, Griffith University, Nathan, Australia; ${ }^{b}$ Griffith Centre for Social and Cultural Research, Griffith University, Nathan, Australia; 'ANU College of Engineering \& Computer

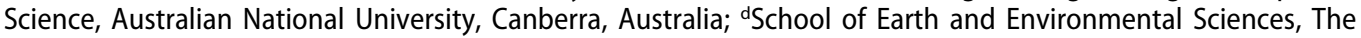

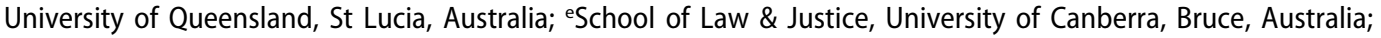
fSchool of Geography, University of Melbourne, Parkville, Australia; 9Pacific Island Council of Queensland, Runcorn, Australia

\begin{abstract}
This paper explores Indigenous (im)mobilities in the Anthropocene, and their relationship to Pacific Islands climate activism. In a context where Indigenous peoples and perspectives are poorly represented in global climate politics, it is important to understand how Pacific people represent their own interests and imagine their own futures as pressures to move due to climate change take hold. We examine political action outside of formal governance spaces and processes, in order to understand how Indigenous people are challenging state-centric approaches to climate change adaptation. We do so by studying the works of Pacific activists and artists who engage with climate change. We find that *banua - an expansive concept, inclusive of people and their place, attentive to both mobility and immobility, and distributed across the Pacific Islands region - is essential for the existential security of Pacific people and central to contemporary climate activism. We find that Pacific activists/artists are challenging the status quo by invoking *banua. In doing so, they are politicising (im)mobility. These mobilisations are coalescing into an Oceanic cosmopolitanism that confronts two mutually reinforcing features of contemporary global climate politics: the subordination of Indigenous peoples, perspectives and worldviews; and the marginalisation of (im)mobility concerns within the global climate agenda.
\end{abstract}

\section{KEYWORDS}

Mobility; Anthropocene; Pacific Islands; Oceanic cosmopolitanism; *banua

\section{Introduction}

The Pacific Islands region has become a place where the politics of climate change and mobility manifest. Climate change mobility in a world of bordered states is sometimes conceived as a 'problem', solutions to which are conceptualised to include in-situ adaptation, disaster risk management, humanitarian assistance, and various forms of complementary or discretionary protection. However, Pacific Indigenous scholars have long argued for their mobilities to be captured in expansive oceanic concepts such as 'Our sea of islands' (Hau'ofa 1993), 'Our sea of phosphate' (Teaiwa 2005), 'Moana' (Māhina 2008) and 'Va' (Lilomaiava-Doktor 2009). Yet, in a climate change context, mobility is often rejected by leaders and activists who state they would prefer to stay on Indigenous land than relocate (e.g. Farbotko, Stratford, and Lazrus 2016). Non-Indigenous scholars, arguably, have an obligation to engage with Indigenous understanding of (im)mobilities in the Anthropocene: while anthropogenic environmental change in the Pacific Islands includes the influences of Indigenous activity, its most significant causes have been non-Indigenous, associated with colonialism and climate change. In the interests of climate 
justice, significant work needs to be done to observe, listen to, understand, and engage with representations of Indigenous (im)mobilities, a task we take up here in the context of Pacific Islander climate change activism. ${ }^{1}$ We think it is imperative for non-Indigenous people, particularly those who are engaged in climate change 'solutions' (such as UNFCCC Conference of Parties negotiators, donors, practitioners and researchers) to attempt to understand Indigenous (im)mobilities, however imperfectly, in the interests of reshaping international policy and knowledge frameworks that tend to be dominated by Western worldviews (Teaiwa 2018). However, Indigenous claims about Anthropocene (im)mobilities are not simply a call for inclusion within extant state-led and state-centric processes and debates about the 'climate-migration nexus'. Rather, we assert - in solidarity with many Oceanic scholars, activists and artists - that contemporary, globally-oriented articulations of Indigenous conceptions of stasis and movement, bound up as they are in Pacific cosmologies, reveal the inability of the political imagination that underpins global climate change governance to countenance other ways of moving through a warming world (see also Baldwin and Bettini 2017, passim). Here, we engage with the notion of *banua, a concept that focusses on people and their customs, land and place, encompasses both mobility and immobility, and extends across the Pacific Islands region. This paper explores how Indigenous activists and artists are translating *banua to the wider warming world.

The Pacific Islands region has attracted heightened global attention in light of challenges in the Anthropocene, not least in relation to human mobility (Campbell 2014). Although global in reach, the Anthropocene's effects are spatially differentiated. The effects of intensifying global resource exploitation and degradation are felt in the region, and have arrived through distant activities associated with industrialisation and the global expansion of capital. The Pacific Islands act as a spatial prism through which injustices and inequities inherent to anthropogenic climate change are reflected and some of its worst effects realised (Farbotko 2010). That said, we look beyond generalised or dramatised narratives of doom ('sinking islands', etc.) frequently tainting analysis of epochal challenges in the region (McNamara and Farbotko 2017), and focus on how inhabitants of the region themselves conceive of challenges and curatives. A prominent concern is that regional risks to land, habitability and livelihoods are unequivocally linked to risks to tradition, culture and identity (e.g. Tiimon 2016). The Anthropocene, in other words, presents existential threats, and these are intimately and foremost understood to be tied to place and culture.

We recognise that the Anthropocene is not simply a temporal geological marker of human impacts on the world's climate, but is an emergent historical conjuncture engendered by worldspanning carboniferous histories of industrialisation, capitalism and colonialism which give rise to a distinctive political conjuncture (Ghosh 2016; Suliman 2016). This political conjuncture sees the modern political master concepts of sovereignty, nation, territory, security, humanity, human rights and citizenship being challenged from above and from below (Johnson et al. 2014; Chakrabarty 2017). From above, securitising nation-states and hyper-mobile capital have attempted to insulate themselves from the harms of the Anthropocene and from those most harmed by climate change effects (Baldwin 2014). From below, however, there have been manifold political mobilisations by many constituencies - including Indigenous peoples - that have sought to highlight that the global political order is ill-equipped to produce durable and just solutions to the wide range of political, economic and social calamities that will be produced or amplified in the Anthropocene (e.g. Okereke, Bulkeley, and Schroeder 2009; Baldwin 2017; Nightingale 2017).

In this context, Indigenous peoples - as we demonstrate below - seek to play a prominent role in debates about climate change resistance, mitigation and adaptation including in relation to climate change and (im)mobility. It is likely that people inhabiting environments that are most susceptible to climate impacts will have to negotiate climate (im)mobility. ${ }^{2}$ For small island societies in the Pacific Islands region, rising sea levels, declining freshwater reserves, loss of biodiversity, changing seasonal conditions and coastal erosion make climate mobility a real possibility (whether through 'migration', 'displacement' or 'relocation') (Barnett and McMichael 2018). 
However, mobility is a highly differentiated experience, and will be shaped by political, economic, environmental and cultural concerns (Lilomaiava-Doktor 2009). We reflect on such issues with reference to a history in which both emplacement and movement have historically interacted to enable Pacific Island life (Hau'ofa 1993).

This paper will expand understandings of climate change and mobilities in the Pacific Islands by reading some of the narratives and performances of Pacific Island climate change artists/activists from the perspective of *banua, an ancient concept shaping past, present and future Indigenous mobilities in the Pacific. The ancient Austronesian concept of *banua suggests an unfolding, emergent and yet holistic system across space and time; a complex network of mobilities and immobilities connecting people, ancestors, stars, canoes and other vessels, ocean, islands and continents. This system, perhaps best conceptualised as a dynamic cosmological compass, originated in South-East Asia with the ancestors of Pacific Islands settlers. ${ }^{*} B a n u a$, as we discuss, forms a cultural scaffold for past, present and future (im)mobilities in and around the Pacific Islands, and provides an orientation for thinking about Anthropocene (im)mobilities within and beyond the region. By engaging with contemporary artists' expression of *banua as an act of cosmopolitan translation, we position their work as Oceanic cosmopolitanism that politicises (im)mobility to imagine other ways of pursuing climate and mobility justice (Sheller 2018).

Activist practices on climate change among Pacific Islanders include art, performances, song, dance and poetry as well as direct actions, speeches, interviews, articles/blogs and theses. We view the insurgent power of Indigenous activists/artists as derived from the ways they politicise (im)mobility by invoking *banua to challenge the global politics of climate change (in)action. Importantly, we show that contemporary mobilisations by Pacific climate change activists are coalescing into an Oceanic cosmopolitanism. This cosmopolitanism confronts two mutually reinforcing features of contemporary global climate politics: the subordination of Indigenous voices; and the marginalisation of (im)mobility concerns from the global climate agenda. These confrontations open space for thinking about alternative ways of navigating the (im)mobility challenges in the Anthropocene. By politicising (im)mobility in this way, Oceanic cosmopolitans insist that the global climate change regime can be remade in a way that seeks to protect rightful places for those whose life-worlds are threatened by climate change.

\section{Indigenous peoples and climate change}

While this paper is primarily concerned with cultural and aesthetic expressions of Pacific peoples' conceptions of movement, place and belonging, the broader context of Indigenous political action to climate change (and alternative climate futures) is important for two reasons. First - amidst vast diversity of geographical locations, colonial histories, and eco-social and political imaginaries - the 'fourth world' is unified by disproportionate experience of adverse climate change impacts. Second, there is a need to avoid collapsing Indigenous peoples into one category of climate vulnerable population, who can then be conceived as the subjects of ultimately insufficient acts of remedy by national governments and intergovernmental organisations (cf. Cameron 2012). Attention to particular climate activisms underscores the diverse political accounts and world-making practices of Indigenous climate activism (cf. Mignolo 2000). As we show in this and subsequent sections, the sidelining of Indigenous perspectives from climate governance (specifically governance of climate (im)mobilities) is being challenged by actors and activists from the Pacific, who are recuperating and mobilising Indigenous perspectives on movement, place and belonging to articulate their demands for mobility justice as an integral component of climate justice (Sheller 2018, see also Fröhlich and Klepp 2018).

Many Indigenous peoples, including those living in the tropics, the Arctic and other fragile ecosystems are experiencing high levels of vulnerability to climate change (IPCC 2018). Such vulnerability is compounding or producing insecurities for many Indigenous people, including many Pacific Island Indigenous peoples. The anguish this can generate is expressed by Maria Tiimon, a well-known i-Kiribati climate change activist: 'At times, it feels as if there is no light at all in the tunnel and I fear 
for the future of my country Kiribati and of course, the rest of the world' (Tiimon 2016). The precarious situation Tiimon highlights is often amplified by political marginalisation, histories of dispossession, and a lack of sufficient recognition of Indigenous people at national and global levels.

The state-centric architecture of the climate change regime is more responsive to the vulnerability of entire states or regions than to particular groups within states (Marino 2012). Thus, historically, Indigenous issues have been obscured. Indigenous peoples were not mentioned in the United Nations Framework Convention on Climate Change (UNFCCC) or in the Kyoto Protocol (Smith and Sharp 2012). The Preamble of the Paris Agreement, however, encourages state parties to consider their obligations towards the rights of Indigenous peoples when taking action to address climate change and in climate action (UNFCCC 2015). Recent Intergovernmental Panel on Climate Change (IPCC) Assessment Reports (AR4 and AR5) include references to Indigenous peoples, in regional chapters (e.g. the Arctic), noting Indigenous peoples' histories of adapting to changes in resource availability and ecological conditions, the contemporary challenges they face, and the potential of Indigenous knowledge for monitoring and adapting to climate impacts (IPCC 2007). For some Indigenous people, including those that make up majority populations in Pacific Islands, it is possible formally and directly to represent their interests in international fora (such as the annual Conference of the Parties to the UNFCCC), as political leaders are often Indigenous. Indigenous populations are also represented through country delegations, or make efforts to influence negotiations and public opinion through diverse channels: e.g. the Indigenous Peoples constituency (coordinated by the International Alliance of Indigenous-Tribal Peoples of the Tropical Forests), submissions to the UNFCCC secretariat, dissemination of written material, or through international NGOs lobbying on their behalf (Schroeder 2010).

Despite these and other recent developments, discussed below, many Indigenous people remain un- or under-represented in formal multilateral climate governance. Yet Indigenous activists and their various partners are working at and beyond the limits of the UNFCCC to respond to climate impacts. Activity includes grassroots resistance to the carbon market, fossil fuel extraction and deforestation, areas where the climate justice and Indigenous Rights movement often share concerns (Long, Roberts, and Dehm 2010). Indigenous People's organisations have also engaged in debates around REDD (reducing emissions from deforestation and degradation) to highlight risks to the rights of Indigenous and forest-dependent communities. Indigenous rights groups such as the Indigenous Environment network have opposed REDD, describing it as ' $\mathrm{CO}_{2}$ lonialism of forests' (cited in Long, Roberts, and Dehm 2010, 232). There are emerging examples of Indigenous climate resiliency plans such as the Salish-Kootenai Tribe's Climate Change Strategic Plan, advocacy documents such as the Inuit Petition expressing 'the right to be cold,' conferences organised by the Indigenous Peoples Climate Change Working Group, numerous declarations such as the Mandaluyong Declaration of the Global Conference on Indigenous Women, Climate Change and REDD+, and academic papers such as a special issue of Climatic Change devoted to Indigenous peoples of North America (Whyte 2017, 153). The 2004 Arctic Climate Impact Assessment (ACIA) - requested by the Ministers of the Arctic Council, and the first comprehensive multi-disciplinary assessment of climate change impacts in the Arctic - was inclusive of Indigenous peoples and Indigenous knowledge. The ACIA included participation of six circumpolar Indigenous peoples' organisations (see also Martello 2008).

Hicks and Fabricant $(2016,88)$ have suggested that efforts to mobilise culture and indigeneity to challenge hegemonic conceptions of development, global environmental protection and climate justice are having important effects on the international community. In Bolivia, climate justice activists have drawn on a vision of Andean indigeneity to support political claims about their rights in relationship to the environment and to propose alternatives to destructive capitalism (Fabricant 2013). The World's People Conference on Climate Change and the Rights of Mother Earth was convened in Tiquipaya, Bolivia in 2009: environmental activists, labour organisers and Indigenous peoples met to discuss climate change issues ranging from climate debt to carbon trading. The later landmark Cochabamba meeting in Bolivia set in motion a transnational climate justice approach that questioned the assumption that the UN would adequately address the climate 
crisis. It aimed to give greater voice to civil society, Indigenous groups, and those from countries most affected by the effects of climate change (see People's Agreement of Cochabamba 2010).

In the Pacific, the Pacific Climate Warriors are similarly mobilising global and regional communication on the effects of climate change. Commencing in 2011-2012, this group of young Pacific Islanders - brought together under the mantra 'we are not drowning, we are fighting' - has grown into an extensive network, active in 15 countries, empowering young people to understand and take action to protect their island homes. The Warriors, with the support of 350.org (an international NGO which originated in the U.S.), have organised direct actions including the 2014 blockade of the Newcastle coal port in Australia. When reflecting on this particular action, Milañ Loeak, a prominent Marshallese activist and Warrior, stated:

... these are our homes. This is a culture that might be gone for a long time if we let climate change keep going, if we let these climate impacts continue. And we're here strongly for that reason because these are our homes. We do not want to see them gone, and I believe have a culture that is so beautiful that we can share with a lot of people around the world and that's what drove us here. You know, there were risks that were involved during the action [Newcastle coal blockade] but I think we were more fearful about the risks that would happen - that would take place - if we didn't stand up and do something about it (in Adventist Record 2014).

Direct actions by the Pacific Climate Warriors push back on external characterisations of Pacific Islanders as passive victims of climate change impacts, through solidarity and a collective identity that is about fighting for their survival (McNamara and Farbotko 2017). The marginal position of Indigenous people in formal climate politics is also challenged by increasingly prominent Pacific Island artist/activists, many of whom are also Pacific Climate Warriors. Kathy Jetñil-Kijiner is a Marshallese poet who gained international prominence in her address at the opening of the United Nations Climate Summit in New York in September 2014. She is also a Pacific Climate Warrior. Jetñil-Kijiner writes about the critical role of Indigenous people in the climate movement, and the ways Indigenous people's knowledge and experiences can be co-opted for political ends. Her work emphasises traditional knowledge of climate, highlighting how Indigenous people have been witnessing and experiencing local climatic changes well before 'scientists'. She rejects the appropriation of Indigenous people into 'green' agendas, and recognises the Earth as an active entity:

Indigenous people are trotted forward as mouthpieces, mined for their wisdom, highlighted for their tragedies, and then shoved to the back of the line. And yet we've seen, over and over again, what happens when Indigenous people are not included in the conversation ...We are here to remind others, industrialized nations, leaders, major industries, that the earth has always been alive - that the land has eyes. It remembers. It will continue to remember. Long after we leave it (Jetñil-Kijiner 2015).

The articulation of Pacific voices through different media has intersected with the formal machinations on climate governance in important ways. In 2017, Fiji became the first Pacific Island state to host the UNFCCC COP. In this forum (held, not in Fiji, but in Bonn), the Warriors became a significant voice for the climate struggles of indigenous peoples to be heard. During COP23, the Pacific Island Warriors issued the 'Pacific Climate Warrior Declaration on Climate Change' (https://haveyoursei.org), and presented framed copies printed on tapa cloth to Pacific environmental leaders. This occurred in the context of a symbolic and rhetorical shift towards inclusive dialogue and cooperation, under the leadership of Fiji, based on the concept of 'Talanoa', 'the Pacific tradition of constructive story-telling, finding shared understanding and moving forward together' (Winkler and Depledge 2018, 141; Pacific Media Watch 2017). However, neither Pacific Climate Warriors' activism, nor the 'Talanoa spirit', have radically changed the course or tenor of negotiations on contentious issues:

While there was much lip-service paid to the Talanoa spirit at Fiji-in-Bonn, ... COP 23 was marked by the usual positioning and bickering between developed and developing countries - and various groups among them that has plagued the climate negotiations since their inception (Winkler and Depledge 2018, 141).

A year later, at COP24 in Katowice, Indigenous climate leaders and activists won an important and rare victory. Amidst tense, drawn out and occasionally hostile negotiations over the 'post-Paris 
Rulebook', 'the Facilitative Working Group (FWG) was established to develop a workplan for the "Local Communities and Indigenous Peoples Platform"' (Carmen 2018). The Platform was established the previous year, at COP 23 in Bonn, under the Presidency of Fiji. It was to set up as a 'formal channel for indigenous peoples' views and interests to be communicated to the UNFCCC process' (UNDP 2018). Sitting within the Subsidiary Body on Scientific and Technological Advice (SBSTA), the Platform is intended to:

preserve and strengthen indigenous and local knowledge systems, enhance the engagement of local communities and indigenous peoples in the UNFCCC process and integrate their considerations in to climate change policy and action (United Nations Climate Change 2018).

This new governance mechanism is envisioned to amplify both particular and common concerns of Indigenous peoples in the global climate change governance agenda. Moreover, the Platform provides the only direct mechanism for formal, direct and putatively equal participation within a UN body, with the FWG comprised of seven Indigenous representatives and seven representatives of State parties (Carmen 2018). While this level of formal representation for Indigenous peoples in UNFCCC processes is unprecedented, whether it enables substantive climate justice for Indigenous peoples remains to be seen.

Indeed, the potential for unfettered inclusion of Indigenous perspectives on climate action is compromised by its emergence and position within a governance assemblage that overall undervalues Indigenous peoples, and their perspectives. While some Indigenous peoples wield some influence over aspects of negotiations as members of Party or Observer delegations, collective negotiating rights within the UNFCCC are not still not conferred. Arguably, then, the Platform fails substantively to reform the relationship between powerful states (and non-state interests) and Indigenous peoples within the UN system. These difficulties are reflected by the post-Paris rulebook agreed in Katowice, with only a handful of references to 'Indigenous Peoples' (including a footnote recognizing the adoption of the new Platform), but no specific reference to the Rights of Indigenous Peoples (Carmen 2018).

This continues a long-standing tendency to marginalise Indigenous voices within global climate governance, which is geared towards a depoliticised conception of climate change adaptation (see Klepp and Chavez-Rodriguez 2018, passim), and maintains 'market-based' (i.e. capitalist) approaches to climate change solutions (Ciplet and Roberts 2017). Within the UNFCCC, Indigenous worldviews are subordinate to scientific and technocratic visions of effective climate change mitigation and adaptation to be achieved through market mechanisms and state-led technical cooperation. Indigenous knowledges are seen to complement (rather than disrupt) the scope of action within formal governance spaces (Smith and Sharp 2012; Sagan 2019).

Indigenous knowledges are not recognised as the basis for action in multilateral climate governance. They are viewed as specialised and localised forms of expertise and practice that may contribute to the transition towards low-carbon and resilient global economies, but only in that they enable Indigenous peoples to act in situ to reduce their own vulnerability and improve adaptive capacity. As Cameron (2012) argues, the 'vulnerability and adaptation approach' to climate change governance in the Arctic region relies on climate science as the basis of climate governance. It systematically elides the structural calamities rendered by colonialism and its ongoing legacies, and obscures the injustice of ongoing dispossession of Indigenous peoples thrugh state violence and damaging developments. Cameron's critique draws attention to the ways in which the inclusion of Indigenous peoples as objects of climate governance (especially through the vulnerability and adaptation lens) confines Indigenous political struggles over climate change to the scale of the local. Thus, while they might now enjoy more visibility within the UNFCCC process, representation of Indigenous people is not commensurate to their aspirations, demands and mobilisations for survival and justice on a global scale. So while there is diversity in Indigenous people's struggles in the face of global climate change, the actions and statements of Indigenous collectives also signal unity of experiences vis-à-vis the historical determinants of climate vulnerability. However, current multilateral negotiations do not adequately address Indigenous peoples' conjoined concerns of climate justice and the decolonisation of world politics. 
The Anthropocene and climate change often represent 'mega-categories' that can conceal Indigenous peoples and their laws, cultures and philosophies. As Todd $(2016,6)$, an Indigenous feminist scholar, notes 'it is easier for Euro-Western people to tangle with a symbolic polar bear on a Greenpeace website or in a tweet than it is to acknowledge arctic Indigenous peoples and their knowledge systems and legal-political realities'. Indigenous scholars and activists, however, point out that climate change represents an intensification of environmental change imposed on Indigenous peoples by colonialism (Whyte 2018; Callison 2014; Watt-Cloutier 2015). While many environmentalists decry the impacts of the Anthropocene, First Nations and Indigenous activists argue that the interconnected traumas of colonialism and ecological decline - including climate change impacts - must be addressed. Whyte, a Potawatomi scholar-activist $(2017,153)$, writes that the perspectives of Indigenous peoples 'arise from memories, knowledges, histories, and experiences of oppression that differ from many of the non-Indigenous scientists, environmentalists, and politicians who are prominent in the framing of the issue of climate change today'. In light of the challenges of climate change and a legacy of colonialism, it is important to engage with contemporary Indigenous struggles to understand the limits of formal mechanisms of climate change governance, and to envisage alternatives that satisfy the aspirations of Indigenous people in a changing climate, including the people of the Pacific.

\section{Anthropocene (im)mobilities and insurgent cosmopolitanisms in the Pacific}

There is wide agreement that human mobility and climate change will be integrally linked. Yet despite the creation of a specialised 'Taskforce on Displacement' within the Warsaw International Mechanism on Loss and Damage, there has been little ground made in integrating broader (im) mobility concerns into international agreements on climate change. This is a problem because the 'loss and damage' of unwanted or insecure climate (im)mobilities for Indigenous peoples will be acute, particularly where these (im)mobilities affect knowledge systems and ways of living, and where climate impacts adversely affect phenomena that cannot be captured by standard metrics such as landscapes (e.g. ice fields, coasts), places (e.g. neighbourhoods, villages), place attachments, cultures, sense of belonging, material artefacts (e.g. burial sites), everyday practices (e.g. gardening), and occupational identities (see Barnett et al. 2016, 977). Climate-related displacement, more particularly, is a concern for many Indigenous activists and scholars as it echoes removals that occurred as part of U.S. colonial, capitalist, and industrial expansion, including displacement and forced occupation of reservations (e.g. Trail of Tears) and the removal of children to boarding schools (Whyte 2017). Further, for many Indigenous peoples, unequal geographical distribution of mobility rights compounds and conceals the ways they have been dispossessed of their right to self-determine their capacity to move (or stay) within or across national boundaries (cf. Sheller 2018; Hackl 2018; Klepp and Herbeck 2016; Papastergiadis 2010). In the Pacific, the right and capacity to move (or stay) for Indigenous and subject populations was colonised along with their lands. As Banivanua Mar $(2016,40)$ has noted, most Indigenous peoples in the Pacific had autonomy of mobility until partition and containment into imperial territories, whereby 'Pacific worlds shrank during the formal colonial era and the expansiveness of trans-Pacific trade and movement was replaced with sanctioned contraction and isolation'. Anthropocene (im)mobilities, then, have the potential for amplified loss and damage particularly where Indigenous social systems have already been impacted by centuries of settler colonialism (see Bronen et al. 2018).

Mobility is widely positioned as problematic, undermining possibilities of negotiating new relationships between movement and emplacement for Indigenous peoples of the Pacific region (cf. Marino 2012). The securitisation of regional politics and mobility, prioritisation of national security and economic growth, refugee and asylum seeker detention systems, discipline of mobile labour through formal immigration systems, and prioritisation of global governance norms on migration and mobility have all contributed to this problematisation (Klepp and Herbeck 2016). In the Pacific Islands, people were often portrayed as passive victims waiting to be saved from their sinking islands by benevolent climate 
cosmopolitans (Farbotko 2010). While this simplistic account is being eroded, mostly by Pacific Islanders highlighting the problems with such a discourse, there is still much to be done to appreciate complex cultural, social, political and economic attachments to place. Some scholars, technocrats and political elites attempt to force climate-affected peoples into the artificially rigid categories of 'refugee', 'economic migrant', 'internally displaced person' and 'migrant worker', often before the climate-affected have even decided that mobility is an acceptable option. Such debates defer to the 'national' as the unit of analysis and elide the importance of both place-connections and alternative conceptions of movement to the security and well-being of vulnerable peoples. By locating these dynamics in a (post)colonial context, it is important to acknowledge that political elites in the region play a part in upholding these logics. Some, such as the former President of Kiribati Anote Tong, pursue more humane and migrant-centric approaches to the challenges to national sovereignty and sustainable development imposed by the 'climate-migration nexus', while others have collaborated with successive Australian governments and private firms to maintain the Australian extra-territorial, regional refugee detention system that also works to structure mobility in and beyond the region (Mountz 2011; Gleeson 2016).

Historical forms of mobility and immobility that were constitutive to both colonial and postcolonial political projects are now shaping contemporary politics of Anthropocene mobilities, in the Pacific and elsewhere. As Mimi Sheller $(2018,11)$ tells us, mobilities research enables a focus not only on movement, but on 'mobility assemblages - constellations of actors, actions, and meanings that are influenced by mobility regimes that govern who and what can move (or stay put), when, where, how, under what conditions, and with what meanings'. The 'new mobilities paradigm' has pushed the boundaries of the research of anthropologists, political economists, political geographers, and scholars from other disciplinary locations engaged in the study of movement in contemporary social and political systems (Schapendonk et al. 2018). As King and Skeldon $(2010,1640)$ note, mobilities research has moved towards demonstrating that 'mobilities create an integrated system, which can be observed at a range of scales: family/household, community, national, and the constellation of countries linked by migration flows'. Glick Schiller and Salazar (2013) highlight the role of individual states and changing international regulatory and surveillance administrations that affect individual mobility, and refer to migration regimes 'in which there are constant struggles to understand, query, embody, celebrate and transform categories of similarity, difference, belonging and strangeness' (Glick Schiller and Salazar 2013, 189). This suggests that ways of governing (im)mobilities are at once normative and open to change.

Notwithstanding this progress, the new mobilities paradigm is yet to consider substantively the meaning, means and modes of politicising (im)mobility by peoples that have been consigned to 'mobility poverty' through histories and experiences of colonialism, capitalism, and climate change. As Sheller $(2018,2)$ reminds us, '... meanings are the ways we make sense of and tell stories about the particular space-time contexts that we make, transform, and inhabit through our ongoing lived (im)mobilities'. The meanings attached to movement, including by Indigenous peoples, is central to unfolding Anthropocene (im)mobilities in the Pacific. The future of the Pacific region is often indexed to the 'refugee scenario' - the idea that Pacific people can only hope to find escape from their sinking islands (see Farbotko 2010), to seek protection and succour elsewhere. To counter this, Carter (2014) argues that 'solutions to the challenges of climate change may be found couched in Indigenous knowledge frameworks rather than in a refugee scenario' and, suggests that the challenge is to develop 'from within the vast network of relationships with both land, sea and other Pacific dwellers' (Carter 2014, 66).

In the Pacific, both planned and ad hoc relocation due to the impacts of climate and environmental change are currently a reality for a few households and communities. Ursula Rakova, from Papua New Guinea is director of not-for-profit organisation Tulele Peisa, and led the relocation of people from the Carteret Islands to Bougainville. In an interview with the Australian public broadcaster, ABC Radio, Rakova (2016) stated that climate change threatens the existence of the Carteret Islands and that the process of relocation to mainland Bougainville 'hasn't been easy' as there are ongoing negotiations with host communities, and the need for funding for resources, transportation, counselling services, agricultural programs, among many other needs. While relocations and displacements are not yet widespread in the region, environmental and economic manifestations 
of climate change will place pressures on individuals and communities to move, and pressure on communities to accommodate people on the move. In this case, myriad social, political and economic anxieties and conflicts loom, while others are already manifest (Farbotko, Stratford, and Lazrus 2016). Significantly in the Pacific Islands, however, claims are often made by Pacific Indigenous people that they would rather stay than relocate away from indigenous territory (Farbotko 2018b). Farbotko (2018a), for example, documented the following excerpt of a speech made by a Pacific Climate Warrior, Arianne Kassam, to Tuvaluan migrants in Australia:

Two decades ago, a foreign scientist visited a small Pacific island. He was a climatologist, and he spoke to the people there. His message was frightening and clear. On the eve of the new millennium, he said, the island would sink under the sea forever. The scientist left the island after that, never to be seen there again. On the night of the new millennium, the people of the island dressed in white. They gathered together on the beach. They sang hymns and prayed, waiting for the sea to rise up. They wanted to stay with their God, their land, their ancestors, and their ocean. The people waited on the beach till dawn. The island was still there, and the sea was no higher than usual. The people went back to their homes and thanked God for saving their island.

For Indigenous people choosing to stay and die is a powerful assertion of indigeneity and an acknowledgement of the limits of nation-state solutions. Pacific Islanders are acutely tuned into the global politics of border control, and reject the highly problematic spaces and processes associated with these such as political refugee camps and climate refugee categories (Farbotko and Lazrus 2012; Stratford et al. 2011; Barnett 2010). Climate change activisms such as these hint at the limits of the climate adaptation orthodoxy, which starts from the assumption that the 'national order of things' (Malkki 1995) can be taken as the only horizon for renegotiating the global and the local to preserve secure and dignified mobility futures (see also Baldwin 2014).

As noted above, Indigenous peoples are making their voices heard and their actions felt in the formally-sanctioned sites and spaces of global climate governance. For example, Indigenous views are promoted and rehabilitated in the face of technocratic and developmentalist conceptions of climate change adaptation (Whyte 2017). As indicated earlier, Pacific climate activists often state that they don't need 'science' to tell them their homes are changing. Rather, their knowledge of change is derived from traditional understanding and lived experiences. For example, Ursula Rakova (2016) made the case in an ABC Radio interview that she doesn't need science and facts to tell her that climate change is happening:

I can see the islands going before my own eyes... disappearing before my eyes... We have lost our food crops, our gardens have gone, our fruit trees have gone, our nut trees have gone, our coconut trees have fallen, our palm trees have gone... I don't need facts to prove that it is climate change... People have no food, and these are vulnerable people who basically have not caused any harm to anybody. What's happening in my island and with my people affecting my people - is something they have not caused. They are basically suffering, or are vulnerable to impacts of something that was caused [a] long, long time ago and by other people (Rakova 2016).

Another example comes from Tongan Olympian, Pita Taufatofua, who has noted: 'People were throwing figures at me about climate change, and I said, "All I know is that each year I walk out and I see the seas coming closer"' (Taufatofua in Murray-Atfield 2018). Taufatofua is an Olympic athlete who gained social media fame following an appearance at the 2016 Summer Olympics and then began publicly campaigning about climate change in his country, in a relatively spontaneous and yet thoughtful harnessing of the attention on his sporting prowess, and consequent visibility.

However, Indigenous political activisms (centred around counter-hegemonic claims to development, sustainability, rights and belonging) sit at odds with the architecture and dominant institutional logics of the global political system through which climate politics are being prosecuted. This system is inherently state-centric, sedentarist, anthropocentric, developmentalist, ahistorical and universalist (Da Costa and Mcmichael 2007; Weber 2007; Santos 2006; Suliman 2018). There is, therefore, a need to understand contemporary Indigenous climate activisms in terms of the political imaginaries that they express, and the alternative spatialities and temporalities with which they engage. Specifically, we argue Pacific activists achieve this through genuine human 
connections, solidarity, a sharing of Pacific cultures and activism as spiritual practice, and that these expressions of Pacific culture and knowledge politicise Anthropocene mobilities at a time when generic, frequently non-committal policy concerning climate mobility and immobility is cropping up particularly in global fora and institutions (e.g. Cancun Adaptation Framework, the UNFCCC Taskforce on Displacement, Platform on Disaster Displacement, Global Compact on Migration).

Examples of this come from the many performances held throughout Europe and the USA, that illustrate, through dance, storytelling and song, Islanders' love and interconnectedness with land and ocean, the sacrifices of their ancestors, and the threats posed by climate change impacts and a call for action. Dance in particular is used in these performances and other direct actions as it can be a form of prayer. One of the performers/dancers in the 'Water is Rising' tour in the USA, Frances Tebau from Kiribati, stated: 'This is our only hope, go for renewable energy. If you could reduce your greenhouse gases... We don't want to lose our land. We will lose everything' (cited in Ayers 2011).

Direct actions by the Pacific Climate Warriors also provide insights into how these human connections and solidarity are built. Milañ Loeak, discussing the flotilla that disrupted Newcastle's coal port in October 2014, argues:

\begin{abstract}
You know... the flotilla might not have made even the slightest bit of difference to the mining companies, but I think we really did have an effect on a lot of people that were there. You know, there were moments when everybody got emotional, and then the next moment you're all singing and dancing, and I felt that the culture that we brought here was beautifully displayed that day, and I think we were effective in that we reached out to the local people here, and we touched somebodies' lives by bringing what we believed in - our cultures and our sense of, you know, unity together. And just getting a lot of support from the local communities, I feel that was a result of what we've done. So, yeah, I think we were effective (Adventist Record 2014).
\end{abstract}

Another prominent Pacific Climate Warrior that works for 350 Pacific, Fenton Lutunatabua from Fiji, made the following case:

A large part of what shapes whether we stand a fighting chance in this battle against the giant fossil fuel industry, depends on how we build and wield the people power base we have as Pacific Islanders and as nations. We need to build a generation of Climate Warriors trained to stand up for the Pacific and build on our authentic and inherent truths, strengths and aspirations (Lutunatabua 2014).

Rather than assimilating Indigenous political activism into a state-centric institutional assemblage, we view contemporary activism - in form and content - in terms of an Oceanic cosmopolitanism. Following Boaventura de Sousa Santos, we consider contemporary Pacific artists/activists as reflecting an 'insurgent cosmopolitanism' that includes, among others, the activities of Indigenous movements and associations' and literary, artistic and scientific movements on the periphery of the world system that are in search of non-imperialist, counter hegemonic cultural values. For Santos, insurgent cosmopolitanism

... consists of the transnationally organized resistance against the unequal exchanges produced or intensified by globalized localisms or localized globalisms.... insurgent cosmopolitanism is no more than a global emergence resulting from the fusion of local, progressive struggles with the aim of maximizing their potential in loco (however defined) through translocal/local linkages (Santos 2006, 397-398).

Cosmopolitanisms are actually located and practiced outside of the European philosophical traditions. With an emphasis on translation and exchange, we are inspired by Delanty's (2014) conception of cosmopolitanism which is avowedly political, in as much as it is invested in renegotiating politico-ethical boundaries through establishing connectedness through difference. Nikos Papastergiadis complements this by suggesting that cosmopolitanism also needs to be considered through cultural translation, which is a mode of comprehending and evaluating cultural similarities and differences (Papastergiadis 2011, 1-2). For Papastergiadis (2011), 'cultural translation entails a commitment to imagining an alternative community', and that the understanding of cosmopolitanism as cultural translation that Delanty offers demands recourse to creativity and imagination to make the very act of translation cosmopolitan: 
Translation exists not because there can ever be precise equivalence between different languages, but from the endless agona to make your culture viable and extend its visibility amidst the global forces of dispersion. It thrives in the desire to bring your culture into the cosmopolitan dialogue (Papastergiadis 2011, 16-17).

Recalling Cameron (2012), a common tendency in political thought and in policy worlds is to disregard Indigenous peoples' capacity to think and act beyond themselves, and to affect change through cosmopolitical acts (see also Forte 2010). Amidst the global swirl of counter-hegemonic struggles, we locate the emergence of activist/artists movements in the Pacific Islands that seek to politicise what it means to be in the Pacific and of the Pacific in a changing climate. The activists/artists discussed here are not one unified bloc, nor do they speak with a unified voice, or create a unified aesthetic. Rather, in voicing, dancing, singing and picturing their concerns, their people and their place in a warming world, these activists/artists coalesce into a polyvalent vision of world politics that places climate change front and centre. Echoing Jacques Ranciere's (2010) musings on aesthetics and politics, we view these works as forms of 'dissensus' that disrupt the 'common sense' of climate politics, and the proper place of discussions of mobility therein.

To focus on arts, then, is to consider the ways in which the ineffable nature of climate change impacts in the Pacific can be acknowledged. Considering such aesthetic injunctions together as an irruptive form of public diplomacy, Oceanic cosmopolitanism - we show below - presents as a regional consciousness that seeks to renegotiate and redefine the Pacific Island people's relationship with the physical, social and political world, and open new ways of thinking about (im)mobility, justice, belonging and sustainable futures in the Anthropocene. The political significance of this diverse movement derives from the power of art to convey difficult truths that remain concealed by the grammar and form of a technological and depoliticised climate political regime, in service of a productive politics in Oceania that attunes to *banua, and thus tends to culture, home place, future and loss for Pacific people.

Our reading of Oceanic cosmopolitics enriches mobilities research by revealing intersections of scale, movement and meaning in ways that confound the orthodox imaginary. This approach also allows us to perceive the predominating scales of mobility governance - the (inter)national - as being both contingent on mobility assemblages, and contestable through nascent and established kinetic heterodoxies. By exploring how Anthropocene (im)mobilities are being contested by Pacific peoples, by presenting their own struggles against a warming world and for a just future, we can better understand how Pacific people are speaking back to the global order that continues to contain and dictate responses to the changing climate. Thus, by engaging with Oceanic cosmopolitics in this way, we can locate questions of (im)mobility more centrally in the global politics of climate change, and find answers that satisfy those most affected by the forms of loss that remain unaccounted for in global climate governance.

\section{Loss, *banua, and politicising mobility through arts and activism}

The Pacific region contains thousands of islands of remarkable geological and ecological diversity, which are home to populations with diverse cultures and livelihood strategies. Although early human history in the region was marked by cases of resource exhaustion and anthropogenic species extinction, overall human life largely flourished over time through adaptation to in situ resource and ecosystems constraints, particularly before the era of European colonisation. Life in the pre-colonial era entailed interplay between emplacement (socio-cultural interaction with land) and regional mobility (socio-cultural interaction with distance and the sea) amongst a 'sea of islands' (Hau'ofa 1993).

The ancient concept of ${ }^{*}$ banua can elucidate some of the Indigenous (im)mobilities of significant portions of the Pacific Islands, namely Polynesia (including Hawaii and New Zealand, whose Indigenous people arrived by canoe from other islands in Polynesia), parts of Micronesia, and also Melanesian Fiji. Here, derivatives of the Austronesian concept of *banua are central to cultural, social and political life. The ancestors of Pacific Islanders were, it is believed, the first in the world to navigate out of sight of land. A pivotal moment in Pacific indigeneity arguably occurred when the 
first double-hulled voyaging canoes navigated - by reading the stars, clouds, currents, wind, creatures and tides - across the expanses of the Pacific Ocean. This happened, according to archaeologists, when people first canoed out of the Solomon Islands towards Fiji, Samoa and Tonga more than 3000 years ago. It is now widely accepted that this navigation, which resulted in the first migration to and settlement of the previously uninhabited islands of the Pacific, was willing and deliberate. The ancestors of today's Micronesians and Polynesians were, it seems, the first in human history to experience the ocean out of sight of land, without becoming lost. This feat was possible with a thorough knowledge of the interconnectedness of people, vessel and environment, embodied in the figure of the navigator. A way of being part of the ocean had been discovered, that was defined as much by island absence as watery presence.

The Anthropocene, which coincides with colonialism and industrial development, is noted for dramatic cumulative and multiscale human impacts upon the earth's human production systems, ecosystems and geology, not least those arising from anthropogenic climate change. According to Marshallese poet Kathy Jetñil-Kijiner, the upshot of the industrial revolution and capitalism is that: 'catastrophe will hit if humans do not make radical changes to our lifestyles of consumption and greed. The world will turn on us. Super storms and massive droughts, extinction and rising seas' (JetñilKijiner 2015). Matching global trends, the Pacific region is noted for having experienced rising air and sea surface temperatures in recent decades; rainfall has become more variable and ocean acidification, contributing to coral bleaching, is occurring (CSIRO et al. 2015). Sea level rise, along with the occurrence of sea level extremes (storm surges, etc.), has increased (ibid.). In its 5th Assessment Report, the IPCC noted that, cumulatively, coastal populations, settlements and infrastructure, those predominating in island locations, will be in a position of increased risk due to sea level rise - amongst them risk of submergence, risk of water availability, and risk to health and to cultural sites (Wong et al. 2014, 381ff). With respect to human populations in small islands in particular, the IPCC highlights the vulnerability of their lands to, amongst other things, extreme tides, waves and surge events, resulting in populations potentially relocating into sometimes more precarious locales (Nurse et al. 2014, 1623). The IPCC observes that in small islands, it is conceivable 'that there is the potential for human movement as a response to climate change, though climate change-related factors no doubt interact with others' (Nurse et al. 2014, 1625).

Scientific reporting on the region in the Anthropocene frequently masks what is by all accounts a hugely emotional and politically charged phenomenon. Unemotive reference to a 'potential for human movement as a response to climate change', stands in stark contrast to the dramatic imagery conjured up by now common-place phrases such as 'drowning islands', which have been propagated, as well as substantially critiqued, elsewhere (e.g. Bettini 2013, 2014; Farbotko 2012; McNamara and Gibson 2009). Yet neither sensationalism nor the bland objectivism of scientific reporting present a satisfactory way to conceptualise climate change (im)mobility and its politics in the Pacific Islands. Both simply reinforce colonial imaginaries about the dangers of mobile Others and the potential of Science to identify problems and perhaps solve them. Neither allow any substantive space for Indigenous worldviews beyond superficial recognition of Indigeneity.

Pacific climate activists/artists commonly express a deep sorrow for threats to and loss of culture and place, including practices, traditions and rituals due to changing environments. Many pose the question of what will happen to their culture with rising seas and intensifying weather extremes. As expressed in the opening press statement describing the performance 'Moana: The Rising of the Sea' which toured Europe in 2015:

For anyone who has lived or lives on an island surrounded by the deep, beautiful, but dangerous sea, the thought that one day your island will be submerged under water and everyone and everything on it will disappear is a possibility too cruel to contemplate. And yet, this is happening in several islands in Oceania already, with more Islanders contemplating their imminent demise and what that would mean to them as a people, a culture, even a nation (Moana press release, 2015). 
This performance, using music, dance and drama, invites the audience to reflect on what it would mean and how would it feel to be forced from their homes as a way of drawing attention to the most pressing issue for the Pacific Islands region. The despairing tone is countered with a message of hope. The performance culminated in a sense of mobility-as-hope, formed from a hybridisation of global and Pacific Indigenous knowledges: 'Maybe, like a double-hulled canoe, western science and indigenous knowledge will safely navigate us out of these dangerous waters? This is the hope in Moana: The Rising of the Sea.'

However, the dynamism of home was not threatening until manifested primarily in changes to sea level. The consequence is that a balance has been disrupted:

Mother nature is pissed. Luerkoklik is destroying me... is destroying all of us (Jetñil-Kijiner 2015).

I have been passionately advocating against climate change because of my deep sense of fear that our islands will one day be wiped off the map, due to the rising sea levels (Jetñil-Kijiner 2016).

In her work Repatriate 1, Latai Taumopeau performed a traditional Tongan dance inside a clear tank. The tank fills with water until she is completely submerged. The work has been described as follows:

Repatriate I: A woman dances her inherited Pacific Island movement vocabulary in a perspex tank. Swathed in flotation devices, the body is protected, as the tank fills with water and submerges the artist. In an embodied response to climate change, Repatriate highlights the ever-nearing possibility of dispossession for island communities. With her own body as the central focus, Taumoepeau probes existing power structures that perpetuate violence and lead to the devastating loss of cultural heritage (Taumopeau 2018).

Taumoepau seems to be making a point about the limits to global cooperation, political will and humanitarian intervention. Her submersion is a call for immediate action on climate change, since tragedy is occurring in the present. Playing on the audience's knowledge that ultimately her physical safety is ensured by the onlookers themselves, who can take comfort in knowing that they would never allow the 'performance' waters to drown her while they stood by, the onlookers must nevertheless question the very act of standing by: is it enough to ensure physical safety, but not necessarily the cultural heritage that is at risk from rising sea levels?

The ability of Pacific Island ancestors to navigate canoes out of sight of land was arguably key to a cosmological transformation, becoming a way of defining a people and their destiny as proud navigators in their sea of islands (Hau'ofa 1993; Finney 2003; Kyselka 1987). This navigating is mobility conceptualised in terms of stillness of the navigator's canoe in a moving, changing cosmos (Farbotko 2012). This is from accounts of those today who are rediscovering and living the almost lost navigating knowledge of their ancestors (e.g. the Polynesian Voyaging Society). So the navigating self is still. It is the ocean and stars that are mobile. Land also moves from its absence over the horizon toward the canoe:

For Pacific Islanders the ocean is not an alien element. It is not something to be feared, conquered or controlled. It is home.... to the initiated, the ocean was a network of pathways connecting the living not only to each other, but to the voyages of their ancestors, and to the gods (Howe 2006).

Navigation strongly resonates in poems by Kathy Jetñil-Kijiner and others. In her poem, 'tell them', Kathy encourages fellow Marshallese to tell everyone they meet about the people and culture of the Marshall Islands:

tell them we are a proud people

toasted dark brown as the carved ribs

of a tree stump

tell them we are descendants

of the finest navigators in the world

tell them our islands were dropped

from a basket

carried by a giant 
tell them we are the hollow hulls

of canoes as fast as the wind

slicing through the pacific sea

...

tell them we are papaya golden sunsets bleeding

into a glittering open sea

we are skies uncluttered

majestic in their sweeping landscape

we are the ocean

terrifying and regal in its power (Jetñil-Kijiner 2011)

Pacific Island history is thus cosmologically centred in a navigable ocean of moving islands. This centeredness was famously discussed by Epeli Hau'ofa in his decolonialising, Pan-Pacific vision of Pacific indigeneity as 'our sea of islands' (Hau'ofa 1993). Hau'ofa pointed out that the lives of many Pacific people, characterised by movement and migration, are informed by notions of the largeness of the Pacific Ocean as a connected 'sea of islands' rather than by the smallness of discrete land masses. This mobility is bound up in *banua, the ancient Austronesian concept thought to originate in Taiwan. *Banua was brought to the Pacific Islands by the Pacific navigators; it travelled with the first oceangoing canoes and endured yet also transformed over thousands of years as the speakers of Austronesian languages travelled from Taiwan, through South East Asia and only later out into the Pacific Islands and New Zealand. Archaeologists call this whole region Austronesia, its people can thus be considered Austronesians, sharing linguistic and cultural roots. As the early Austronesians variously navigated, explored, drifted, invaded, and were exiled across Austronesia until the vast majority of its many islands were inhabited, they took *banua with them. Across local variations in culture that emerged, generally, all forms of *banua retained in common a similar meaning derived from the common root: 'an inhabited territory which included the village and its population together with everything that contributed to the life support system of that community' (Blust 1987).

According to Taiwanese anthropologist of Fiji Hao-Li Lin $(2015,28)$ 'to the Austronesian settlers the "land" is where societies are made, where identities are rooted, and where the pasts can be remembered. It cannot be understood separately as natural environment outside the human realm passively waiting to be occupied and utilised. Instead, it is active and encompassing with a life of its own'. The distribution of *banua across the Pacific Islands, moreover, is interconnected and hybrid and has a universality that endures beyond local variations, evidenced in its endurance through the millennia and travelling with the settlers even as their cultures, languages and identities diverged:

On the universal level, fonua entails the dialectically changing formal, substantial and functional relationships within and between nature, mind and society... On the unique level, however, fonua espouses the historically shifting ecological, psychological and sociological connections within and across fonua (birth), fonua (living) and fonua (death), as conflicting physical, emotional and human processes of eternal cycle and exchange (Māhina 2008).

Thus, an active culturally and physically nourishing *banua in the Pacific Islands seems to endure before, during and beyond the spatial and temporal passages of those who call it home. *Banua in the Pacific Islands is defined as a way of navigating the moving cosmos. For Latai Taumopeau, the Tongan performance artist, her cultural identity is tied to her fonua, but the fonua is mobile:

My fonua (placenta) buried in the Eora Nation/Baime Dreaming (Sydney, Australia) nourishes my belonging to this land with my ancestral roots embedded in my Island Nation, The Kingdom of Tonga (in majeurenews 2015).

In this instance, a very specifically Pacific, but also hybrid, cosmopolitan cultural identity is claimed in a new land, Australia. Similarly, the navigational quality of *banua is evidenced in the notion of Hawaiki, a Polynesian mythological homeland without a unique physical manifestation. Hawaiki has an uncertain meaning, seeming to shift over time and across space as people shifted, sometimes appearing in mythology as an original homeland, other times appearing as part of the underworld, and sometimes thought of as not a place but a group of chiefly ancestors (Taumoefolau 1996). 
Starting with the pivotal moment of navigating out of sight of land thousands of years ago, and arguably becoming sure of themselves, their place, where they came from and their destiny, local variations of *banua remain, in the contemporary Indigenous Pacific world. They are cornerstones of a dynamic, changing Pacific Ocean as home, its islands each individually significant, but also, to some extent, malleable and mobile in the cosmological realm. This is not to say that the local variations are unimportant; on the contrary, particularly in the era of the nation-state, they have become extremely significant. Tevita (2008), for example, translates 'tangata'ifonua' and 'fefine'ifonua' as male and female of the land respectively, and explains that this is the Tongan way of speaking of an Indigenous person, while 'fonua encompasses the spiritual and genealogical oneness of land and its people' (Tevita 2008). Local forms of *banua, though currently seen as, for example, distinctly Fijian or Tongan or Tuvaluan, are actually typically sub-national, and nevertheless share roots in *banua. For example, Tuvalu has eight 'fenua', each corresponding to one of its eight traditionally inhabited islands.

Peters and Steinberg $(2014,128)$ observe that, from a Western perspective, 'if you are unaware of a last position, a lost object at sea is nigh on impossible to find, even if it is floating on the surface'. Central to *banua, however, is being continually aware of one's position in a moving cosmos. The inhabitants of the Pacific can, arguably, never lose themselves, because they have positioned their indigeneities in terms of masterful oceanic navigating, finding absent islands, and nurturing the cycle of life. Through *banua, Pacific Islanders understand and know their home; physically in an ongoing act of keeping track of one's position on the ocean when out of sight of land and spiritually in terms of a constant repositioning of the self with reference to the moving cosmos. Their ancestors knew, and today's traditional voyaging revivalists (such as the Polynesian Voyaging Society) are discovering that they have the ability to always find themselves on a vast ocean, both materially and culturally:

The good news is that we [The Polynesian Voyaging Society] found thousands of people there full of aloha, full of compassion and caring for the Earth and for the oceans, which give us our life. The news from the Pacific is not good. Yet the spirit of the people we met on the voyage leaves me feeling incredibly strengthened and inspired (Nainoa Thompson, President of the Polynesian Voyaging Society, quoted in Schiffman 2017).

The Polynesian Voyaging Society signifies a research and cultural revival. It is increasingly recognised as an environmental education group widely known throughout the Pacific Islands, and indeed beyond, for remastering the Pacific Indigenous knowledges of canoe-building and navigation, that enabled prior generations to explore and settle the islands. The group educates and raises awareness about the mobilities and oceanic expertise central to many Pacific cultures, building and sailing vaka (doublehulled voyaging canoes) on many voyages. As Farbotko $(2012,129)$ observes, central to these voyages is 'the notion of taming the ocean. Pacific people's sense of history is invested with power from being "at home" on the ocean. Journeying is thus a way of being at home'.

While it seems that *banua can never be lost, loss of land due to climate change is experienced by many Pacific Islanders as existential insecurity. Pacific peoples' relational cosmology allows for dynamic configurations of terrestriality and fluidity, of kinesis and stasis, but with the important caveat that navigating voyagers could (and can) see themselves as the centre of the moving ocean. The denial of this capability - by way of the loss of agency to determine their (im)mobile futures in the political conjuncture of the Anthropocene - threatens to deliver profound forms of existential insecurity. Many Pacific people feel that mobility is no longer available on their terms. Colonialism curtailed their navigation and exploration of the ocean, confining Pacific Island people to villages, and hence many may have lost sight of the mobile possibilities of *banua which their ancestors were free to explore. The confines of the nation-state, with its rigid border controls, sedentarism, and ultimately poor support of mobile people who do not fit the criteria of wealthy, industrialisedworld passport-holder, work strongly against Pacific Island people finding their own mobile destinies in a changing climate. Thus there are many utterances of 'we will stay here and die', which is not a passive fatalism, but, as Arianne Kassam's story indicates, an active choice and a political resistance to non-indigenous 'solutions' such as international relocations. 
Contemporary Pacific poets are bringing their resilience and resistant politics to the forefront of their activism:

most importantly tell them

we don't want to leave

we've never wanted to leave

and that we

are nothing without our islands.

(Jetñil-Kijiner 2011).

While there are existential threats of climate change to lives, livelihoods, culture and place, no-one wishes to leave their home place, which is the emotionally-moving end of Kathy Jetñil-Kijiner's poem 'tell them'. This existential insecurity is expressed as rendering people as 'nothing' if they choose to leave. 'The Caregiver's Story' poem by Evelyn Flores also captures the severity of the problem, and their dismissal by others because of small relative populations and remoteness:

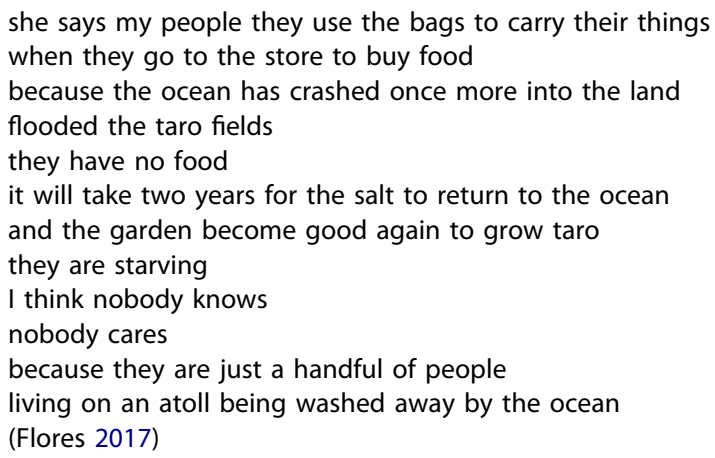

Without denying the extreme significance of loss of land, however, ${ }^{*}$ banua is not necessarily at risk in the Anthropocene. Expansive, open and shared across the multiple indigeneities of the Pacific Islands since original settlement, *banua seems likely to endure beyond the Anthropocene through ongoing, changing and yet also eternal mutual custodianship of life with ancestors and descendants. The mobile nature of *banua is lived in Pacific Island diasporas in places like New Zealand and Australia, and is likely to survive even the worst case scenario of complete loss of habitability of some islands. *Banua is likely to continue to offer cosmological resilience in a changing climate, even in the face of individual, family, community or national despair arising from loss of land in the *banua, possibly in new, as yet unknown ways and perhaps most importantly, whether remaining on or leaving degraded lands amid rising seas, its people can continue to nourish *banua and be guided by it. A partial balm, perhaps, to the experience of profound existential insecurity. Craig Santos Perez expressed in a poem - 'Praise Song for Oceania' - how people, culture and place, past, present and future are all inter-linked and connected, an 'endless saga':

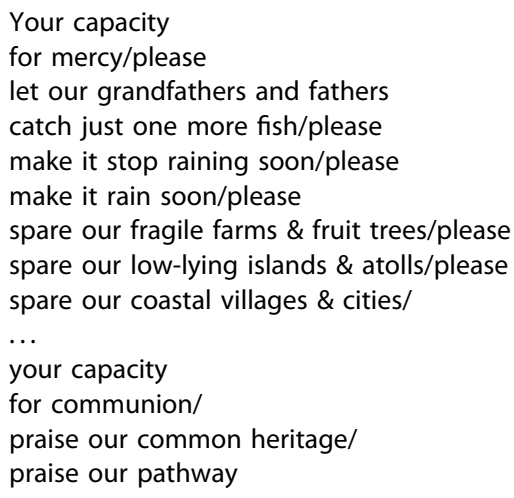


\& promise to each other/praise

our endless saga/praise our most powerful

metaphor/praise this vision

of belonging/praise your horizon

of care/praise our blue planet,

one world ocean/praise our trans-oceanic

past, present \& future flowing

through our blood/(Santos Perez 2018, 179-182)

Contemporary Pacific cosmopolitan projects are beginning to engage with the spatial rupture to cosmology by highlighting and recuperating mobilities and expansive interconnection (Teaiwa 2018). They are, therefore, politicising (im)mobility at a time when many climate vulnerable peoples in the region have diminishing desire to move - perhaps when mobility is more important than perhaps ever before. Importantly, this diverse cosmopolitan project is occurring in part through artistic and aesthetic spaces, in which Pacific climate change activism expresses concerns about loss, culture, place and *banua in the context of changing climates.

\section{Conclusion}

We contend that, as a matter of climate justice, deeper engagement with Indigenous (im)mobilities in the Anthropocene is necessary. Indigenous struggles against and within the context of climate change deserve treatment and analysis that reach beyond common conceptualisations involving national representation, global civil society mobilisation or multilateral negotiations. We have found that Pacific poets, dancers, orators, and others have collectively positioned the existential threat of climate change as an object of local political action and activism originating from their cosmological world. Basing their expressions in permutations of *banua - concerning the relationship between movement and stillness, kinesis and stasis - creates possibilities of pondering the pressing realities of climate change from within a historical context rich in experience of journeying, of losing sight of land, of proud navigation, and of starting over. These amount to Indigenous cosmopolitanisms, which ask difficult questions of hegemonic conceptions of territorial space and political time, and which raise the stakes of critical discussion about mobility in the political present. The confrontations laid bare in the process create novel space for thinking about alternative ways of navigating the mobility challenges arising in the Anthropocene.

\section{Notes}

1. Only one author is an Indigenous Pacific Islander.

2. Farbotko and McMichael (forthcoming) distinguish a notion of voluntary immobility from 'trapped populations.' This latter concept gained prominence in the UK Government's Migration and Global Environmental Change Foresight report (Foresight 2011). It refers to impoverished people who are unable to move from environmentally high-risk areas due to lack of resources required to move, with this socio-economic vulnerability further amplified by the erosion of livelihoods via climate change impacts (Foresight 2011; Nawrotzki and DeWaard 2018). AyebKarlsson, Smith, and Kniveton (2018) argue that labelling a person or population as 'trapped' can, like the term 'vulnerable', potentially reduce recognition of agency and thus limit independence and self-determination. In contrast, the notion of voluntary immobility commences with the perspectives, agency and rights of people who do not want to leave their homes and homelands (Farbotko and McMichael forthcoming).

\section{Acknowledgments}

We thank the special issue editors, particularly Andrew Baldwin, and the two anonymous reviewers of this paper.

\section{Disclosure statement}

No potential conflict of interest was reported by the authors. 


\section{ORCID}

Samid Suliman (iD) http://orcid.org/0000-0001-6354-1750

Carol Farbotko (iD) http://orcid.org/0000-0001-8257-2085

Hedda Ransan-Cooper (ID) http://orcid.org/0000-0002-9053-0229

Karen Elizabeth McNamara iD http://orcid.org/0000-0002-4511-8403

Fanny Thornton (iD) http://orcid.org/0000-0001-9823-8903

Celia McMichael (iD http://orcid.org/0000-0002-4572-602X

\section{References}

Adventist Record. 2014. "President's Daughter in Climate Change Protest." Interview with Record in Focus, October 30. https://vimeo.com/110522108

Ayeb-Karlsson, S., C. D. Smith, and D. Kniveton. 2018. "A Discursive Review of the Textual Use of 'Trapped' in Environmental Migration Studies: The Conceptual Birth and Troubled Teenage Years of Trapped Populations." Ambio 47 (5): 557-573. doi:10.1007/s13280-017-1007-6.

Ayers, K. 2011. "Pacific Islanders Dance for Sea Rise Awareness." KQED Science, October 17. https://ww2.kqed.org/ climatewatch/2011/10/17/pacific-islanders-dance-for-sea-rise-awareness/

Baldwin, A. 2014. "The Political Theologies of Climate Change-Induced Migration." Critical Studies on Security 2 (2): 210-222. doi:10.1080/21624887.2014.932509.

Baldwin, A. 2017. "Climate Change, Migration, and the Crisis of Humanism." WIREs Climate Change 8 (3): e460. doi:10.1002/wcc.460.

Baldwin, A., and G. Bettini, eds. 2017. Life Adrift: Climate Change, Migration, Critique. London: Rowman and Littlefield.

Banivanua Mar, T. 2016. Decolonisation and the Pacific: Indigenous Globalisation and the Ends of Empire, Critical Perspectives on Empire. Cambridge: Cambridge University Press.

Barnett, J. 2010. "Climate Change, Ethics and Human Security." In Climate Change Science and Policy, as if People Mattered, edited by K. O'Brien, A. Lera, S. Clair, and B. Kristoffersen, 47-62. Cambridge: Cambridge University Press.

Barnett, J., and C. McMichael. 2018. "The Effects of Climate Change on the Geography and Timing of Human Mobility." Population and Environment 39 (4): 339-356. doi:10.1007/s11111-018-0295-5.

Barnett, J., P. Tschakert, L. Head, and W. N. Adger. 2016. "A Science of Loss." Nature Climate Change 6 (11): $976-978$. doi:10.1038/nclimate3140.

Bettini, G. 2013. "Climate Barbarians at the Gate? A Critique of Apocalyptic Narratives on 'Climate Refugees.'." Geoforum 45: 63-72. doi:10.1016/j.geoforum.2012.09.009.

Bettini, G. 2014. "Climate Migration as an Adaption Strategy: De-Securitizing Climate-Induced Migration or Making the Unruly Governable?" Critical Studies on Security 2 (2): 180-195. doi:10.1080/21624887.2014.909225.

Blust, R. 1987. "Lexical Reconstruction and Semantic Reconstruction: The Case of Austronesian 'House' Words." Diachronica 4 (1): 79-106. doi:10.1075/dia.4.1-2.05blu.

Bronen, R., J. K. Maldonado, E. Marino, and P. Hardison. 2018. "Climate Change and Displacement: Challenges and Needs to Address an Imminent Reality." In Challenging the Prevailing Paradigm of Displacement and Resettlement: Risks, Impoverishment, Legacies, Solutions, edited by M. M. Cernea and J. K. Maldonado. Oxon and New York: Routledge.

Callison, C. 2014. How Climate Change Comes to Matter: The Communal Life of Facts. Durham, N.C.: Duke University Press.

Cameron, E. S. 2012. "Securing Indigenous Politics: A Critque of the Vulnerablity and Adaptation Approach to the Human Dimensions of Climate Change in the Canadian Arctic." Global Environmental Change 22 (1): 1-3-114. doi:10.1016/j.gloenvcha.2011.11.004.

Campbell, J. R. 2014. "Climate-Change Migration in the Pacific." The Contemporary Pacific 26 (1): 1-28. doi:10.1353/ cp.2014.0023.

Carmen, A. 2018. "COP 24 in Katowice Concludes with Historic Victory and Some Disappointments for Indigenous Peoples in the International Fight to Halt Climate Change." Cultural Survival, December 27. https://www.cultural survival.org/news/cop-24-katowice-concludes-historic-victory-and-some-disappointments-indigenous-peoples

Carter, L. 2014. "Criss-Crossing Highways: Pacific Traveling and Dwelling in Times of Global Warming." Journal of New Zealand and Pacific Studies 2 (1): 57-68. doi:10.1386/nzps.2.1.57_1.

Chakrabarty, D. 2017. "The Politics of Climate Change Is More than the Politics of Capitalism." Theory, Culture \& Society 34 (2-3): 25-37. doi:10.1177/0263276417690236.

Ciplet, D., and J. T. Roberts. 2017. "Climate Change and the Transition to Neoliberal Environmental Governance." Global Environmental Change 46: 148-156. doi:10.1016/j.gloenvcha.2017.09.003.

Commonwealth Scientific and Industrial Research Organisation (CSIRO), Australian Bureau of Meteorology, and Secretariat of the Pacific Regional Environment Programme. 2015. "Climate in the Pacific: A Regional Summary of New Science and Management Tools." https://www.pacificclimatechangescience.org/wp-content/uploads/2013/ 06/Climate-in-the-Pacific-summary-48pp_WEB.pdf 
Da Costa, D., and P. Mcmichael. 2007. "The Poverty of the Global Order." Globalizations 4 (4): 588-602. doi:10.1080/ 14747730701695851.

Delanty, G. 2014. "Not All Is Lost in Translation: World Varieties of Cosmopolitanism." Cultural Sociology 8 (4): $374-391$. doi:10.1007/s00267-008-9144-0.

Fabricant, N. 2013. "Good Living for Whom? Bolivia's Climate Justice Movement and the Limitations of Indigenous Cosmovisions." Latin American and Caribbean Ethnic Studies 8 (2): 159-178. doi:10.1080/17442222.2013.805618.

Farbotko, C. 2010. "Wishful Sinking: Disappearing Islands, Climate Refugees and Cosmopolitan Experimentation." Asia Pacific Viewpoint 51 (1): 47-60. doi:10.1111/j.1467-8373.2010.001413.x.

Farbotko, C. 2012. "Skilful Seafarers, Oceanic Drifters or Climate Refugees? Pacific People, News Value and the Climate Refugee Crisis." In Migrations and the Media, edited by K. Moore, B. Gross, and T. Threadgold, 119-142. New York, NY: Peter Lang Publishing.

Farbotko, C. 2018a. "Climate Change and Island Populations." In Routledge Handbook of Ethics and International Relations, edited by B. J. Steele and E. A. Heinze, 405-418. Abingdon, Oxon: Routledge.

Farbotko, C. 2018b. "No Retreat: Climate Change and Voluntary Immobility in the Pacific Islands Migration Information Source." Migration Information Source, June 13. https://www.migrationpolicy.org/article/no-retreat-climate-changeand-voluntary-immobility-pacific-islands

Farbotko, C., and C. McMichael. forthcoming. "Voluntary Immobility and Existential Security in a Changing Climate." Asia-Pacific Viewpoint, March 2018.

Farbotko, C., E. Stratford, and H. Lazrus. 2016. "Climate Migrants and New Identities? the Geopolitics of Embracing or Rejecting Mobility." Social \& Cultural Geography 17 (4): 533-552. doi:10.1080/14649365.2015.1089589.

Farbotko, C., and H. Lazrus. 2012. "The First Climate Refugees? Contesting Global Narratives of Climate Change in Tuvalu." Global Environmental Change 22: 382-390. doi:10.1016/j.gloenvcha.2011.11.014.

Finney, B. 2003. Sailing in the Wake of the Ancestors: Reviving Polynesian Voyaging. Honolulu, HI: Bishop Museum Press.

Flores, E. 2017. "The Caregiver's Story." The Missing Slate, October 1. http://themissingslate.com/2017/10/01/the-caregiversstory/

Foresight. 2011. Migration and Global Environmental Change: Final Project Report. London: Government Office for Science.

Forte, M. C., ed. 2010. Indigenous Cosmoplitans: Transnational and Transcultural Indigeneity in the Twenty-First Century. New York: Peter Lang.

Fröhlich, C., and S. Klepp. 2018. "Climate Change and Migration Crises in Oceania." TODA Peace Institute Working Paper 29. Ghosh, A. 2016. The Great Derangement: Climate Change and the Unthinkable. Chicago, IL: University of Chicago Press. Gleeson, M. 2016. Offshore: Behind the Wire on Manus and Nauru. Sydney: NewSouth Publishing.

Glick Schiller, N., and N. B. Salazar. 2013. "Regimes of Mobility across the Globe." Journal of Ethnic and Migration Studies 39 (2): 183-200. doi:10.1080/1369183X.2013.723253.

Hackl, A. 2018. "Mobility Equity in a Globalized World: Reducing Inequalities in the Sustainable Development Agenda." World Development 112: 150-162. doi:10.1016/j.worlddev.2018.08.005.

Hau'ofa, E. 1993. "Our Sea of Islands." In A New Oceania : Rediscovering Our Sea of Islands, edited by E. Naidu, V. Waddell, and E. Hau'ofa, 2-17. Suva, Fiji: University of the South Pacific, in association with Beake House.

Hicks, K., and N. Fabricant. 2016. "The Bolivian Climate Justice Movement: Mobilizing Indigeneity in Climate Change Negotiations." Latin American Perspectives 43 (4): 87-104. doi:10.1177/0094582X16630308.

Howe, K. R. 2006. Vaka Moana: Voyages of the Ancestors. Auckland: David Bateman .

Intergovernmental Panel on Climate Change (IPCC). 2007. "Climate Change 2007: Synthesis Report. Summary for Policymakers." Edited by Intergovernmental Panel on Climate Change. doi:10.1094/PDIS-91-4-0467B.

Intergovernmental Panel on Climate Change (IPCC). 2018. "Summary for Policymakers." In Global Warming of $1.5^{\circ} \mathrm{C}$. An IPCC Special Report on the impacts of global warming of $1.5^{\circ} \mathrm{C}$ above pre-industrial levels and related global greenhouse gas emission pathways, in the context of strengthening the global response to the threat of climate change, sustainable development, and efforts to eradicate poverty, edited by V. Masson-Delmotte, P. Zhai, H.-O. Pörtner, D. Roberts, J. Skea, P. R. Shukla, A. Pirani, et al., 32. Geneva, Switzerland: Geneva, World Meteorological Organization.

Jetñil-Kijiner, K. 2011. “Tell Them.” April 13. Accessed 16 March 2019. https://jkijiner.wordpress.com/2011/04/13/tellthem/

Jetñil-Kijiner, K. 2015. "Luerkoklik and the Role of the Land in the Climate Movement." Accessed 16 March 2019. https://hehiale.wordpress.com/2015/06/26/luerkoklik-and-the-role-of-the-land-in-the-climate-movement/

Jetñil-Kijiner, K. 2016. "On Birthing New Life, and Fresh Possibilities." March 25. Accessed 16 March 2019. https://www. kathyjetnilkijiner.com/on-birthing-new-life-and-fresh-possibilities/

Johnson, E., H. Morehouse, S. Dalby, J. Lehman, S. Nelson, R. Rowan, S. Wakefield, and K. Yusoff. 2014. "After the Anthropocene: Politics and Geographic Inquiry for a New Epoch." Progress in Human Geography 38 (3): $439-456$. doi:10.1177/0309132513517065.

King, R., and R. Skeldon. 2010. "'Mind the Gap!' Integrating Approaches to Internal and International Migration." Journal of Ethnic and Migration Studies 36 (10): 1619-1646. doi:10.1080/1369183X.2010.489380.

Klepp, S., and J. Herbeck. 2016. "The Politics of Environmental Migration and Climate Justice in the Pacific Region." Journal of Human Rights and the Environment 7 (1): 54-73. doi:10.4337/jhre.2016.01.03. 
Klepp, S., and L. Chavez-Rodriguez, eds. 2018. A Critical Approach to Climate Change Adaptation: Discourses, Politics and Practices. Abingdon, Oxon: Routledge.

Kyselka, W. 1987. An Ocean in Mind. Honolulu: University of Hawai'i Press.

Lilomaiava-Doktor, S. 2009. "Beyond 'Migration': Samoan Population Movement (Malaga) and the Geography of Social Space (Vā)." The Contemporary Pacific 21 (1): 1-32. doi:10.1353/cp.0.0035.

Lin, H. L. 2015. "Vanua as Environment: Conservation, Farming, and Development in Waitabu, Fiji." PhD diss., University of Pittsburgh.

Long, S., E. Roberts, and J. Dehm. 2010. "Climate Justice inside and outside the UNFCCC: The Example of REDD." Journal of Australian Political Economy 66: 222-246.

Lutunatabua, F. 2014. "Climate Impacts and the Climate Warriors of the Island Nation of Kiribati." March 28. https:// 350.org/climate-impacts-and-the-climate-warriors-of-the-island-nation-of-kiribati/

Māhina, H. O. 2008. "Closing Remarks: Moana Education: Disciplinary Practice VS. Form of Social Activity." AlterNative: an International Journal of Indigenous Peoples 4 (1): 188-191. doi:10.1177/117718010800400114.

Malkki, L. 1995. "Refugees and Exile: From 'Refugee Studies' to the 'National Order of Things.'." Annual Review of Anthropology 24: 495-523. doi:10.1146/annurev.an.24.100195.002431.

Marino, E. 2012. "The Long History of Environmental Migration: Assessing Vulnerability Construction and Obstacles to Successful Relocation in Shishmaref, Alaska." Global Environmental Change 22 (2): 374-381. doi:10.1016/j. gloenvcha.2011.09.016.

Martello, M. L. 2008. "Arctic Indigenous Peoples as Representations and Representatives of Climate Change." Social Studies of Science 38 (3): 351-376. doi:10.1177/0306312707083665.

McNamara, K., and C. Gibson. 2009. "'We Do Not Want to Leave Our Land': Pacific Ambassadors at the United Nations Resist the Category of 'Climate Refugees.'." Geoforum 40 (3): 475-483. doi:10.1016/j.geoforum.2009.03.006.

McNamara, K. E., and C. Farbotko. 2017. "Resisting a 'Doomed' Fate: An Analysis of the Pacific Climate Warriors." Australian Geographer 48 (1): 17-26. doi:10.1080/00049182.2016.1266631.

Mignolo, W. 2000. "The Many Faces of Cosmo-Polis: Border Thinking and Critical Cosmopolitanism." Public Culture 12 (3): 721-748. doi:10.1215/08992363-12-3-721.

majeurenews. 2015. "10mins with Latai from NOTHING TO LOSE." Force majeure, January 6. https://forcemajeureblog. wordpress.com/2015/01/06/10mins-with-latai-from-nothing-to-lose/

Moana. 2015. "Moana: The Rising of the Sea." Accessed 17 January 2019. https://www.usp.ac.fj/index.php?id=15844

Mountz, A. 2011. "The Enforcement Archipelago: Detention, Haunting, and Asylum on Islands." Political Geography 30 (3): 118-128. doi:10.1016/j.polgeo.2011.01.005.

Murray-Atfield, Y. 2018. "Pita Taufatofua: Viral Tongan Olympic Sensation Sets Sights on Climate Change; Eyes Third Sport." $A B C$ News, April 6. http://www.abc.net.au/news/2018-04-06/viral-tongan-olympic-sensation-sets-sights-onclimate-change/9622648

Nawrotzki, R. J., and J. DeWaard. 2018. "Putting Trapped Populations into Place: Climate Change and Inter-District Migration Flows in Zambia." Regional Environmental Change 18 (2): 533-546.

Nightingale, A. J. 2017. "'Power and Politics in Climate Change Adaptation Efforts: Struggles over Authority and Recognition in the Context of Political Instability,"." Geoforum 87: 11-20. doi:10.1016/j.geoforum.2017.05.011.

Nurse, L. A., R. F. McLean, J. Agard, L. P. Briguglio, V. Duvat-Magnan, N. Pelesikoti, E. Tompkins, and A. Webb. 2014. "Small Islands." In Climate Change 2014: Impacts, Adaptation, and Vulnerability. Part B: Regional Aspects. Contribution of Working Group II to the Fifth Assessment Report of the Intergovernmental Panel on Climate Change, edited by V. R. Barros, C. B. Field, D. J. Dokken, M. D. Mastrandrea, K. J. Mach, T. E. Bilir, M. Chatterjee, et al., 1613-1654. Cambridge, UK and New York, NY: Cambridge University Press.

Okereke, C., H. Bulkeley, and H. Schroeder. 2009. "Conceptualizing Climate Governance beyond the International Regime." Global Environmental Politics 9 (1): 58-78. doi:10.1162/glep.2009.9.1.58.

Pacific Media Watch. 2017. "Healers, Not Harmers' - Climate Warriors Present COP23 Declaration." Asia Pacific Report, November 10. https://asiapacificreport.nz/2017/11/10/healers-not-harmers-climate-warriors-present-cop23-declaration/

Papastergiadis, N. 2010. “Wars of Mobility." European Journal of Social Theory 13 (3): 343-361. doi:10.1177/1368431010371756.

Papastergiadis, N. 2011. "Cultural Translation, Cosmopolitanism and the Void." Translation Studies 4:1: 1-20. doi:10.1080/ 14781700.2011.528678.

"People's Agreement of Cochabamba." April 22. 2010. Cochabamba, Bolivia. https://pwccc.wordpress.com/2010/04/ 24/peoples-agreement/

Peters, K., and P. Steinberg. 2014. "Volume and Vision: Toward a Wet Ontology." Harvard Design Magazine 39: $124-129$.

Rakova, U. 2016. "The Interview: Ursula Rakova. Sunday Nights." ABC Local Radio. http://www.abc.net.au/sundaynights/ stories/s4444935.htm

Ranciere, J. 2010. Dissensus: On Politics and Aesthetics. Edited by trans. S. Corcoran. London: Continuum.

Sagan, C. 2019. "Ending the Anthropocene." Public Books, January 22. https://www.publicbooks.org/ending-theanthropocene/

Santos, B. D. S. 2006. "Globalizations." Theory, Culture \& Society 23 (2-3): 393-399. doi:10.1177/026327640602300268.

Santos Perez, C. 2018. "Praise Song for Oceania." Atlantic Studies 13 (2): 176-182. doi:10.1080/14788810.2017.1363578. 
Schapendonk, J., I. van Liempt, I. Schwarz, and G. Steel. 2018. "Re-Routing Migration Geographies: Migrants, Trajectories and Mobility Regimes." Geoforum (Advance onine publication). doi:10.1016/j.geoforum.2018.06.007.

Schiffman, R. 2017. "Fantastic Voyage: Polynesain Seafaring Canoe Completes Its Globe Circling Journey." Scientific American, June 13. https://www.scientificamerican.com/article/fantastic-voyage-polynesian-seafaring-canoecompletes-its-globe-circling-journey/

Schroeder, H. 2010. "Agency in International Climate Negotiations: The Case of Indigenous Peoples and Avoided Deforestation." International Environmental Agreements: Politics, Law and Economics 10 (4): 317-332. doi:10.1007/ s10784-010-9138-2.

Sheller, M. 2018. Mobility Justice: The Politics of Movement in an Age of Extremes. London: Verso Books.

Smith, H. A., and K. Sharp. 2012. "Indigenous Climate Knowledges." WIREs Climate Change 3 (5): 467-476. doi:10.1002/ wcc. 185.

Stratford, E., E. McMahon, M. Jackson, C. Farbotko, and S. Perera. 2011. "Review Forum: Reading Suvendrini Perera's Australia and the Insular Imagination: Beaches, Borders, Boats, and Bodies, Suvendrini Perera, Palgrave Macmillan, New York (2009), Vii + 228 Pp.; Bibliog; Index. US \$85.00 (Hardcover), ISBN 978-0-230-61353-9." Political Geography 30 (6): 329-338. doi:10.1016/j.polgeo.2011.06.001.

Suliman, S. 2016. "Rethinking about Civilizations: The Politics of Migration in a New Climate." Globalizations 13 (5): 638-652. doi:10.1080/14747731.2016.1204129.

Suliman, S. 2018. "Mobilising a Theory of Kinetic Politics." Mobilities 13 (2): 276-290. doi:10.1080/17450101.2017.1410367.

Taumoefolau, M. 1996. "From *Sau 'ariki to Hawaiki." The Journal of the Polynesian Society 105 (4): 385-410.

Taumopeau, L. 2018. "Liveworks: Repatriate Part I." Accessed 16 March 2019. http://performancespace.com.au/events/ liveworks-repatriate/

Teaiwa, K. 2005. "Our Sea of Phosphate: The Diaspora of Ocean Island." In Indigenous Diasporas and Dislocations: Unsettling Western Fixations, edited by G. Harvey and C. D. Thompson Jr., 169-191. London: Ashgate Publishing.

Teaiwa, K. 2018. "Moving People, Moving Islands in Oceania." Paradigm Shift 3: 63-69.

Tevita, O. 2008. "Tauhi Vā: Creating Beauty through the Art of Sociospatial Relations." PhD Diss., University of Washington.

Tiimon, M. 2016. "Maria Tiimon Is Building Awareness of How Climate Change Effects Low Lying Islands in the Pacific." 1 Million Women, March 7. https://www.1millionwomen.com.au/blog/women-youre-voice-maria-timon-buildingawareness-how-climate-change-affects-low-lying-islands-pacific/

Todd, Z. 2016. "An Indigenous Feminist's Take On The Ontological Turn: 'Ontology' Is Just Another Word For Colonialism." Journal of Historical Sociology 29 (1): 4-22. doi:10.1111/johs.12124.

UNFCCC. 2015. UNFCCC. Adoption of the Paris Agreement. Report No. FCCC/CP/2015/L.9/Rev.1. http://unfccc.int/ resource/docs/2015/cop21/eng/l09r01.pdf

United Nations Climate Change. 2018. "COP24 Strengthens Climate Action of Local Communities and Indigenous Peoples." December 10. https://unfccc.int/news/cop24-strengthens-climate-action-of-local-communities-andindigenous-peoples

United Nations Development Programme (UNDP). 2018. "Exceeding Expectations in Katowice." December 17. http:// www.undp.org/content/undp/en/home/news-centre/news/2018/exceeding-expectations-in-katowice.html

Watt-Cloutier, S. 2015. The Right to Be Cold: One Woman's Story of Protecting Her Culture, the Arctic and the Whole Planet. Toronto. ON, Canada: Penguin.

Weber, H. 2007. "A Political Analysis of the Formal Comparative Method: Historicizing the Globalization and Development Debate." Globalizations 4 (4): 559-572. doi:10.1080/14747730701695828.

Whyte, K. P. 2017. "Indigenous Climate Change Studies: Indigenizing Futures, Decolonizing the Anthropocene." English Language Notes (ELN) 55.1/2: 153-162. doi:10.1215/00138282-55.1-2.153.

Whyte, K. P. 2018. "Indigenous Science (Fiction) for the Anthropocene: Ancestral Dystopias and Fantasies of the Climate Change Crisis." Environment and Planning E: Nature and Space 1 (1-2): 224-242. doi:10.1177/2514848618777621.

Winkler, H., and J. Depledge. 2018. "Fiji-in-Bonn: Will the 'Talanoa Spirit' Prevail?" Climate Policy Taylor \& Francis 18 (2): 141-145. doi:10.1080/14693062.2018.1417001.

Wong, P. P., I. J. Losada, J.-P. Gattuso, J. Hinkel, A. Khattabi, K. L. McInnes, Y. Saito, and A. Sallenger. 2014. "Coastal Systems and Low-Lying Areas." In Climate Change 2014: Impacts, Adaptation, and Vulnerability. Part A: Global and Sectoral Aspects. Contribution of Working Group II to the Fifth Assessment Report of the Intergovernmental Panel on Climate Change, edited by C. B. Field, V. R. Barros, D. J. Dokken, K. J. Mach, M. D. Mastrandrea, T. E. Bilir, M. Chatterjee, et al., 361-409. Cambridge, UK and New York, NY: Cambridge University Press. 


\title{
Indigenous (im)mobilities in the Anthropocene
}

\author{
Samid Suliman, Carol Farbotko, Hedda Ransan-Cooper, Karen Elizabeth \\ McNamara, Fanny Thornton, Celia McMichael \& Taukiei Kitara
}

To cite this article: Samid Suliman, Carol Farbotko, Hedda Ransan-Cooper, Karen Elizabeth McNamara, Fanny Thornton, Celia McMichael \& Taukiei Kitara (2019): Indigenous (im)mobilities in the Anthropocene, Mobilities, DOI: 10.1080/17450101.2019.1601828

To link to this article: https://doi.org/10.1080/17450101.2019.1601828

曲 Published online: 25 Apr 2019.

Submit your article to this journal

View Crossmark data ־ 